\title{
Editorial
}

\section{Brand essence - making our brands last longer}

At the moment, we seem to be enjoying a respite from shock headlines such as 'Sounding the Death-Knell for Big Brands', 'Is this the end of Brand Management as We Know It?' and even 'Freddie Starr ate My Brand Equity'. The more sensational tendencies among the business press have moved on to newer topics.

Nevertheless, the rate of change in the world continues to accelerate, and this can result in some rather high profile casualties, as changing consumer tastes and aggressive new competitors conspire to oust more long-established brands from their privileged positions in the marketplace.

No matter how big your brand, the choice is still the same - adapt or die. However, there is a paradox facing the strongest brands. Often the brand values that built consumer loyalty in the past are the very same values that are turning off the new generation of consumers. Some brand owners have found that when they change what they say to consumers about their brand, they lack credibility among potential new recruits - moreover, they also alienate their existing consumer base.

This is especially true in markets that are driven by two conflicting needs. For instance, many household cleaners markets are carved up between two brands - one brand majors on high-performance stain removal, and the other plugs into the desire to care for one's family. If the 'caring' brand overemphasises its stain-zapping credentials, it starts to become more harsh and 'uncaring' to the consumer; meanwhile the 'efficacy' brand portrays itself as more caring, which of course implies it doesn't clean as well as it used to.
What is the lesson in all of this? The fundamental one is that brand owners need to stop asking their brands to be what they are not; instead they need to accept what they are and find innovative new ways of re-presenting this to new consumers in a motivating way.

This is where the concept of Brand Essence comes in - the idea that each brand has a core value or set of values that sets out what it stands for. This is the DNA of the brand - its defining values that set it apart from any other brand. It manifests itself through the product, the packaging, price positioning, advertising, PR - all reinforce what the brand stands for in the minds of the consumer. Moreover these defining values do not really change over the years - they simply get reinterpreted for each new generation.

It is vital for all brand owners to really understand the essence of our brands, and to always remain true to the brand essence in everything we do. The huge payoff that comes from following this discipline is that it allows you to say new things about your brand in a way that is credible to a new audience.

Recent Volvo communication offers a textbook example of how it should be done - the dull but worthy image of ultra-safe cars for ultra-conservative drivers has been transformed in the 1990s. They're still talking about safety, which is arguably the brand's core essence, but have found a way of making this core essence much more motivating for today's consumer - by suggesting that saf ety can be exciting too!

Moreover, the new messages can also serve to strengthen the loyalty of existing users insofar as it reinforces the brand's 
essence, which is what caused them to buy in the first place.

In trying to pin down the essence of your brand, there are a few things to bear in mind. Firstly, there is a need to be realistic - don't hide from the truth. Too often, brand owners try and define their essence in terms of where they want to be, which is often exactly where they are not right now! Anyway, most of the time, our core brand values can be seen in a positive or a negative light, depending on how you choose to view them, so its possible to accentuate the positives in your analysis.

Secondly, draw your inspiration from a wide range of sources - consumers, agencies, and employees (both marketing and non-marketing literate). The top-of-mind opinions of these people are important this is often where to find the best clues for understanding your brand essence. For instance, it might be a famous advertising slogan from the past that everyone can quote, eg, Guinness is Good for You. There is also well-known brand symbols (eg, the Nike swoosh, Cadbury's glass and a half), product features (eg, the Levis rivet and triple stitching), or associations with certain types of consumer (eg, the belief that Jack Daniels is the favoured tipple of many well-known rock stars). Its important to draw all these elements out and find the common threads that connect them together - it is here that you often find the essence of the brand.

Once the brand essence is identified, it is important to ensure that all manifestations of the brand reinforce the essence to some extent, or at the very least, do not contradict it. The end result will be a clearer, stronger offering to the consumer that is flexible enough to adapt to changing circumstances - and a brand that can go the distance.

Tim Kelly, Editorial Board 